\title{
Atlantis
}

Critical Studies in Gender, Culture \& Social Justice

Études critiques sur le genre, la culture, et la justice

\section{Saleh, Muna. 2019. Stories We Live and Grow By: (Re)Telling Our experiences as Muslim Mothers and Daughters. Ontario, Canada: Demeter Press}

\section{Shirin Khayambashi}

Volume 40, numéro 1, fall 2019

URI : https://id.erudit.org/iderudit/1066421ar

DOI : https://doi.org/10.7202/1066421ar

Aller au sommaire du numéro

Éditeur(s)

Mount Saint Vincent University

ISSN

1715-0698 (numérique)

Découvrir la revue

Citer ce compte rendu

Khayambashi, S. (2019). Compte rendu de [Saleh, Muna. 2019. Stories We Live and Grow By: (Re)Telling Our experiences as Muslim Mothers and Daughters.

Ontario, Canada: Demeter Press]. Atlantis, 40(1), 61-63.

https://doi.org/10.7202/1066421ar d'utilisation que vous pouvez consulter en ligne. 


\section{Book Review}

\section{Stories We Live and Grow By: (Re)Telling Our Experiences as Muslim Mothers and Daughters}

Shirin Khayambashi is a sessional professor and a $\mathrm{PhD}$ Candidate in Sociology from McMaster University. She is expecting to defend her thesis in December 2019. She is a qualitative researcher who specializes in Diaspora studies and hybrid identity development. Her article "Diaspora, Identity and Store Signs" was recently published in the Journal of Visual Studies. She has further presented her research in a variety of Canadian and American conferences. Her PhD dissertation focuses on the flag debate among the Iranian diaspora. Through her research, she challenges the concept of diasporic cohesion, and questions the issues confronted by minority members of a diasporic community.

Book under review: Saleh, Muna. 2019. Stories We Live and Grow By: (Re)Telling Our experiences as Muslim Mothers and Daughters. Ontario, Canada: Demeter Press.
In Stories We Live and Grow By, Muna Saleh explores the generational re-rooting of the complex and diverse Muslim diaspora through multi-perspective narrative inquiries. She traces and links the Muslim mother and daughter experience, which connects the ancestral past to future generations. As an education scholar, Saleh examines the Muslim daughter's experience with adolescence in the home and school, along with their mother's journey from childhood to motherhood. Saleh argues for the coexistence of school and home in creating a strong educational curriculum which facilitates the healthy development of young Muslim girls. Her analysis includes the interconnection of the cisgender Muslim woman's experience in the religiously, regionally, and racially diverse Muslim diaspora. Saleh indicates that the growing hatred towards the unidimensional image of Muslim women under hijab post 9/11 disrupts the identity development of young Muslim girls. Therefore, the school curriculum must connect home and school by reflecting on Muslim identity to help young Muslim girls to flourish beyond stereotypes and segregating social norms.

Saleh draws upon her experience as a second-generation Muslim woman from a Palestinian and Lebanese background living in Edmonton, Alberta. She travels down her female genealogy to reconstruct her experience in Canada. Due to her familial experience with dislocation and destruction of the original homeland, Saleh indicates the significance of spatiality in the rerooting of each diasporic community. Through her personal narrative, she argues for the importance of the home as a location for the cultivation of future generations. Through narrative inquiries, Saleh explores the intergenerational relationship of three pairs of cis-gender mothers and daughters to comprehend their delicate balancing act among the home, school, media, and the general public. 
As part of the narrative inquiry, Saleh intimately participates in the lives of her co-inquirers. The narrative inquiry includes constant self-reflection and self-evaluation about her own experience with the participants. There is merit to this approach. Through repetition and self-evaluation in each sub-section, she explores different angles of the same narrative, which indicates the complexity of each personal account. The methodology explores the "stories [she] lives by, with, and in"(12). The self-reflection and retelling expose the reader to "embodied experiential knowledge" of each narrative (251).

Through examination of the lives of her co-inquirers, Saleh challenges the contemporary Muslim discourse, which includes the stereotypical image of an exotic and victimized Muslim woman forced under the hijab. Saleh revisits the cultural and ideological aspects of Islam, along with the orientalized discourse of war-on-terror, to investigate the identity development of the young Muslim women in North American societies. For instance, with ongoing restrictive laws, such as the current niqab ban in Quebec, the government gradually normalizes Islamophobia through a hegemonic attack on the hijab. For all Muslim women, whether or not to don the hijab is a personal choice relating to their religious and spiritual beliefs. Saleh poetically describes each woman reminiscing about their challenges, or jihad, relating to choosing to don the hijab or not. While suggesting a personal dilemma about wearing the hijab, Saleh refers to the current political climate and states that Canadian Muslim women are aware that donning the hijab makes them vulnerable and visible in Canadian societies (113). Simultaneously, the Western obsession with, and yet oversimplification of, the hijab silences those who encounter abusive family and unconsented hijab. In Western societies, these women's experiences are rendered invisible in fear of betraying their community. These women are unable to communicate their spiritual crises, as they avoid the labels given to the Muslim community. Saleh critically explores the experiences of Muslim women with their hijab, and she stresses that the hijab is a personal choice between a woman and her Allah.
Through her interactions with her co-inquirers, Saleh criticizes the ingroup contestation, racism, and sexism among the Muslim diaspora. Due to the diversity of Muslim identity, minority status Muslim women encounter racial and gender discrimination by their Muslim community, which leads to ingroup isolation and segregation (241). She argues that the experience of Muslim women is more than their hijab. In school, the community centres, and even among family, women are subjected to criticism by their community regarding the way they practice their religion and culture. Saleh demonstrates how each mother and daughter experience misogyny and racial discrimination in their community and how each employs innovative modes of resistance and rebellion without breaking socio-cultural norms. Each mother and daughter deal separately with the culture of patriarchy in their diaspora, and the Canadian general public, in ways which are both innovative and liberating. Therefore, creative and continuing mothering is necessary for the daughters to grow into independent adults with well-developed identities and strong senses of self.

While Saleh critically explores the experience of Muslim women in Canada, her research lacks intersectionality. Saleh unpacks ingroup and outgroup racism and sexism, but she leaves class, gender, and sexuality unexplored. First, her analysis is devoid of any socio-economic data. Other than a small description of warm homes and abundance of cultural treats, Saleh does not disclose each participant's socio-economic class. It is assumptive that all Muslim women share similar socio-economic class, and all have the leisure to have a proper home/school balance for their children. The socio-economic class of each family indicates their social access and their ability to be involved with their children's schooling. Would all Muslim mothers have similar leisure?

Second, the heteronormality of Saleh's analysis is not representative of the Muslim diaspora. Since Saleh solely focuses on binary cis-gender equality, she limits the scope of her research. For instance, when parents disapprove of mixed-gender parties, Saleh rationalizes 
their action by using a gender binary perspective, indicating both girls and boys are discouraged from attending. While discussion about the parties could be an appropriate premise to discuss the young girls' gender and sexual identity, Saleh rationalizes it maternally. The assumption of gender and sexual identity of the young Muslim participants avoids the questions surrounding the sexuality and gender identity of these young adults. The heteronormativity of this research limits the intersectional analysis of the findings.

While this book is a compelling exploration of Muslim women experience in Canada, lack of gender/sexual identity and class hierarchy renders the analysis incomplete. 